\author{
Al-wardah: Jurnal Kajian Perempuan, Gender dan Agama \\ Volume : 13 No 1. Edisi Juni 2019 \\ ISSN: 1907-2740, E-ISSN: 2613-9367 \\ DOI: $10.46339 /$ al-wardah.v13i1.154
}

\title{
Metode Tafsir Aminah Wadud Untuk Pemberdayaan Perempuan Dalam Ekonomi
}

\author{
Syaifuddin \\ IAIN Ternate, Ternate, Indonesia \\ ifudsby@iain-ternate.ac.id
}

\begin{abstract}
Abstrak
Studi Ekonomi pada masyarakat bertumpu pada entitas keluarga sebagai unit terkecil. Tujuan dari sebuah sistem ekonomi berorientasi pada falah atau kesejahteraan individu. Karena individu sebagai tujuan ahir dari kesejahteraan maka ketimpangan ekonomi berdasarkan gender pasti terjadi dalam masyarakat. Tujuan dari penelitian ini adalah menafsir ulang keadilan ekonomi untuk pemberdayaan ekonomi perempuan melalui metode tafsir Aminah Wadud. Ada tiga kalimat yang mengalami pemaknaan ulang digunakan sebagai metode analisis terhadap beberapa ayat ekonomi yaitu Islam, tauhid dan taqwa. Pembaruan metode tafsir Aminah Wadud digunakan untuk menyegarkan kembali tafsir yang berkeadilan dalam bidang ekonomi, utamanya untuk pemberdayaan perempuan. Tafsir Aminah wadud yang sangat peduli dengan keadilan gender,. Pendekatan tafsir Aminah Wadud juga sangat sesuai dengan pendekatan maqashid syariah dalam merekonstruksi hukum ekonomi syariah. Tafsir Aminah Wadud dan Maqashid Syariah Jasser Audah menyediakan perangkat yang sesuai untuk merekonstruksi hukum ekonomi syariah, dan keadilan ekonomi.

Key words : Metode, Tafsir, Aminah Wadud, Pemberdayaan, Ekonomi, Perempuan
\end{abstract}

\begin{abstract}
Abstrac
Economic studies of society rests on the entity of the family . an economic system oriented to the falah or well-being of individuals. The purpose of this study is to interpret re-economic justice for women's economic empowerment through the method of interpretation of Aminah Wadud. There are three sentences experience a re-interpretation is used as a method of analysis of a few verses of the economy that is Islam, tawheed and taqwa. The update method of interpretation Aminah Wadud to refresh the interpretation of justice in the economic field, especially for the empowerment of women. Interpretation is concerned with gender justice,. The approach to this issue is in accordance with the approach of maqasid of shariah in reconstructing the economic laws of shariah. The second Interpretation provides a device for reconstructing the economic laws of shariah, and economic justice.

Key words : Methods, Interpretation, Aminah Wadud, Empowerment, Economy, Women
\end{abstract}




\section{A. Pendahuluan}

Ekonomi dan kajian ilmu ekonomi memasuki babak baru secara ideologis. Masuknya Tiongkok menjadi kekuatan ekonomi besar dunia bersama Amerika, merubah pandangan masyarakat ekonomi dunia dalam melihat ideologi ekonomi. Sistem ekonomi Tiongkok yang sosialis dalam negara komunis, tetapi dalam beberapa aspek terlihat watak kapitalis. Negara negara Eropa seperti Jerman dan Perancis sudah lama menggunakan sistem ekonomi kapitalis yang mengkombinasikan dengan sistem ekonomi sosialis. Indonesia sejak tahun 1990 an mulai mengkombinasikan sistem ekonomi campuran dengan sistem ekonomi Islam.

Pengalaman berbagai negara tersebut menunjukkan idiologi ekonomi bersifat cair. Sistem ekonomi juga akhirnya berkembang dalam banyak model sistem ekonomi. Berubah ubahnya sistem ekonomi bersifat pragmatis untuk mencapai tujuan ekonomi setiap negara. Tujuan semua sistem ekonomi semua negara hampir sama mencapai ekonomi yang tumbuh dan keadilan yang bermuara pada kemakmuran dan kesejahteraan.

Prioritas Pemerataan atau pertumbuhan ekonomi yang sering membedakan sistem ekonomi. Kapitalis ekonomi lebih berorientasi pada pertumbuhan ekonomi yang tinggi. Sosialis ekonomi lebih berorientasi pada pemerataan ekonomi. Yang kurang mendapat perhatian adalah bagaimana keadilan ekonomi berdasarkan gender. Keadilan ekonomi masih menjadi persoalan besar berupa ketimpangan antara negara maju, negara berkembang dan negara miskin. Ketimpangan Antara negara di belahan utara bumi dan di belahan selatan bumi. Ketimpangan antara negara Barat dengan negara Timur.

Dalam ekonomi Islam, terdapat prinsip penting yang menjadi pembeda ekonomi Islam dengan ekonomi lainnya. Pelarangan riba dalam ekonomi Islam diantaranya karena dalam riba ada eksploitasi dan ketidakadilan. Ba'i najasy atau rekayasa permintaan palsu, dilarang dalam Islam karena ada asimatris informasi atau ketimpangan akses informasi, sebagai ketidakadilan. Asimetris informasi membuat ada pihak yang dirugikan dan diuntungkan. Pelarangan maysir atau gambling dalam 
transaksi ekonomi Islam, sebab dalam transaksi untung untungan ada yang diuntungkan ada yang dirugikan, ketidakpastian menimbulkan ketidakadilan. Terma terma ekonomi Islam sangat menjunjung tinggi prinsip keadilan, sehingga keadilan adalah prinsip utama yang menjiwai ekonomi Islam.

Keadilan Gender, Hak Asasi Manusia dan lingkungan hidup merupakan isu-isu yang mengemuka dalam perkembangan ilmu sosial kontemporer terutama dalam proses pembangunan di dunia ketiga. Amina Wadud merupakan seorang muslim, feminis, dan cendekiawan kontroversi yang concern dengan persoalan gender dalam Islam. Ia lebih dekat sebagai pemikir gender dalam gerakan feminisme yang menitikberatkan kepada hubungan (struktur) gender ketimbang berpusat pada 'masalah perempuan. Ia memperoleh Ijazah Doktor Filsafat dari Universitas Michigan dan tekun mempelajari

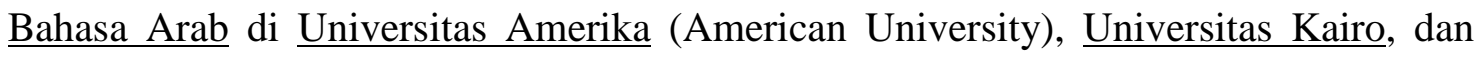

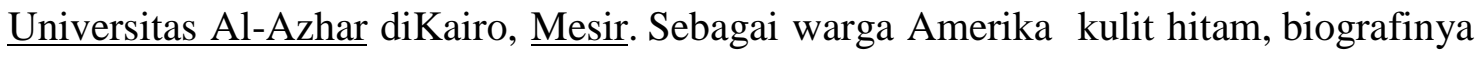
yang penuh warna turut membentuk kepribadian Amina Wadud yang unik. Dalam masyarakat multikultural dengan latar belakang multi etnis, seorang perempuan bahkan mungkin lebih penting daripada kelas. Perempuan kulit hitam dalam masyarakat kulit putih mungkin merasa dirinya jauh lebih setara dengan laki-laki kulit hitam ketimbang perempuan kulit putih. Dapat diterima secara logis, dengan latar belakang tersebut, apabila Amina Wadud mempunyai kepedulian besar terhadap nasib perempuan muslim, melalui produk pemikirannya yang melawan maskulinitas penafsiran, yang tertuang dalam buku Inside G ender J ihad, Women's Reform in Islam.

\section{B. Kajian Teori}

Metode penelitian yang digunakan Amina Wadud adalah dengan menggunakan pendekatan linguistik-Hermeneutik, dengan analisa filologi atau content analysis secara holistik. Lebih lengkapnya, Wadud menggunakan teori double movement dan pendekatan Tematik dari Fazlur Rahman untuk menjelaskan ayat-ayat tentang perempuan. Selain menggunakan hermeneutik gerakan ganda, Wadud juga menggunakan metode tafsir al-Qur'an bil al-Qur'an untuk menganalisa semua ayat- 
ayat yang memberikan petunjuk khusus bagi perempuan, baik yang disebutkan secara terpisah ataupun disebutkan bersamaan dengan laki-laki. Ayat-ayat yang ada dianalisis pada; konteknya, di dalam kontek pembahasan topik yang sama dengan al-Qur'an, tatanan bahasa yang sama dari stuktur sintaksis yang digunakan di seluruh bagaian ayat, sikap yang benar adalah yang berpegang teguh pada prinsip-prinsip universalitas al-Qur'an (Islam).

Wadud menganalisis teks ayat-ayat al-Qur'an, dengan memusatkan pada susunan bahasa al-Qur'an yang bermakna ganda. Prinsip umum al-Qur'an menjadi landasan Wadud dalam rangka mendapatkan pandangan hidup yang cocok bagi perempuan modern saat ini adalah membangun relasi fungsional antara laki-laki dan perempuan dalam interaksi sosial. Wadud membahas juga mengenai konsep diri manusia dan stuktur budaya dominan dari suatu masyarakat, budaya patriarki sebagai suatu struktur dominan yang sangat berpengaruh terhadap konstruksi relasi gender di masyarakat.

Dalam upaya menafsirkan ayat-ayat al-Qura'an dan Hadith, Amina Wadud bukanlah satu-satunya muslimah yang ambil bagian. Dapat disebut bebarapa feminis muslim yang menempuh cara reinterpretasi, seperti : Zainab Fawwaz (Libanon), Huda Sya'rawi (Mesir), Nawal Sa'dawy ( Mesir), Fatima Mernissi ( Maroko), Riffat Hassan (Pakistan), Leila Ahmad (Amerika)dan lainnya.

Amina Wadud menawarkan pemahaan baru terhadap terma seperti Islam, khilafah, tauhid, taqwa dan syari'ah. Beberapa istilah yang penting untuk menafsir ayat ayat ekonomi antara lain Islam, Tauhid dan Taqwa.

Dalam rangka mengeluarkan perempuan dari kekangan endrosentrisme (nilai dominan yang didasarkan pada norma dan cara pandang laki-laki), Wadud melanjutkan pemikiran yang memfokuskan kajian lebih ke aspek kultur, tidak sama antara Islam dengan Arab. Harus bisa dipisahkan antara budaya Arab dan konsep ajaran Islam, Islam tidak sama dengan Arab. Penafsiran terhadap relasi laki-laki dan perempuan 
banyak dipengaruhi oleh tradisi masyarakat dan celakanya hal itu dikira bahwa itulah Islam. Islam punya pedoman hidup yang bernilai Universal, jangan melihat Islam secara partikular sesuai dengan nalar masin-masing suku atau bangsa. Laila Ahmad menambahkan dalam pemahaman terhadap Islam, kita harus melihat dan memetakan bagaimana kultur berintraksi dengan agama, yang berakibat pemahaman yang berbeda pula.

Menurut Wadud, Islam adalah pilihan untuk menyerah kepada Allah (engaged surender), kita punya kesadaran untuk mengikutinya, manusia bersifat aktif untuk memilih, mengikutinya atau membangkang atau yang lainnya. Kesadaran untuk mengikuti kehendak (Abdullah), bagaimana kita mengikuti syari'ah (kehendak Tuhan), sedangkan syariah adalah produk penafsiran, maka kita harus hati-hati memahaminya. Outoritas untuk memilih adalah kesadaran penuh diri untuk menjalankan pesan-pesan moral secara universal dalam Islam, dan semuanya berkewajiban untuk itu jika mereka mengakui bahwa mereka adalah Islam.

\section{Tauhid dan Taqwa}

Bagi Amina Wadud, tauhid adalah prinsip dasar yang digunakan Islam agar manusia (laki-laki dan perempuan) sejajar. Atas dasar Tauhid, ia mengembangkan konsep paradigma tauhid (Tawhidic Paradigm). Tauhid membuka prinsip kesetaraan yang harmonis pada gender, tidak ada kepentingan politik di dalamnya. semua berkesempatan menjadi hamba Allah yang menjalankan perintah-Nya, hambanya yang bertaqwa. Ukuran taqwa lebih bersifat abstraks, penuh pesan moral, karena tanpa membedakan gender, tidak menggunakan ukuran yang bersifat duniawi, kebangsaan, kekayaan, ataupun pada konteks sejarah kecuali pada aspek kualitas tindakan dan sikap hidup manusia, semua bisa menjadi hamba yang bertaqwa dengan syarat menjalankan perintah Allah dalam segala lini kehidupan.

Dalam al-Qur'an dinyatakan bahwa segala sesuatu berupa pasangan, pasangan tersebut merupakan bagian dari sistem dualisme. Semua pasangan, seperti halnya laki- 
laki dan perempuan, tunduk kepada Allah Swt., pencipta semua makhluk. Karenanya, tidak boleh ada satu makhluk yang merasa lebih tinggi dari lainnya.

Sistem al-Qur'an, menggambarkan laki-laki dan perempuan dalam posisi setara (equal) dan bersifat saling melengkapi. Seperti halnya sistem pasangan lainnya yang Allah Swt. Ciptakan, siang dan malam, luar dan dalam, atas dan bawah, adalah berlawanan namun saling membutuhkan dan melengkapi. Hubungan pasangan sepadan manusia tersebut lebih pada dimensi metafisik, bukan fisik. Hubungan manusia dapat diilustrasikan sebagai berikut :

\section{Ilustrasi Paradigma Tauhid}

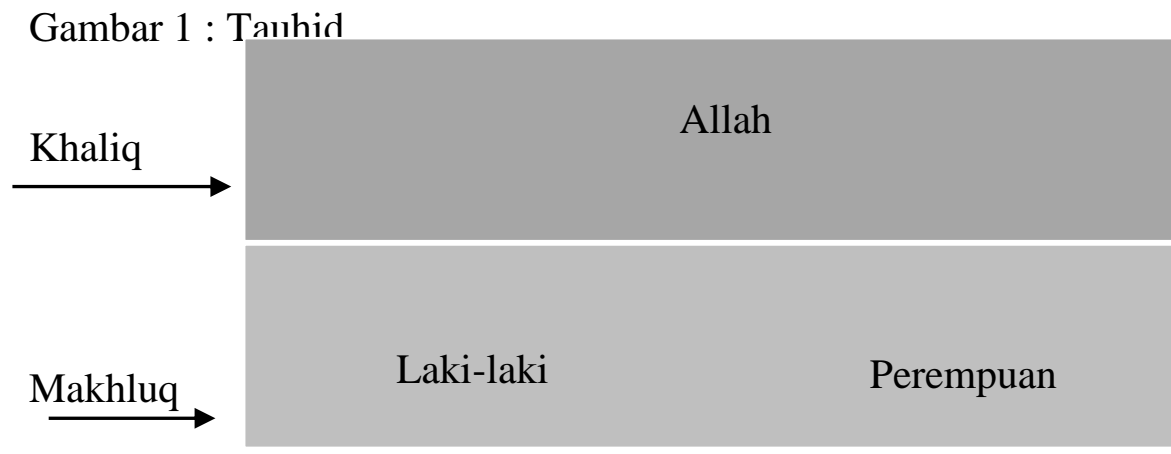

Gambar 2 : Syirik

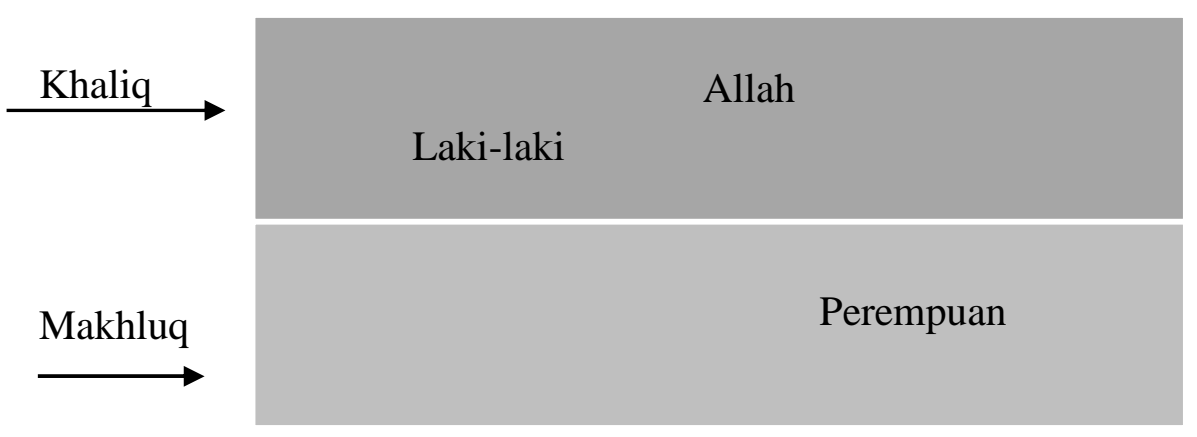

Dalam gambar pertama, posisi laki-laki dan perempuan sejajar secara metafisik, karena moral tertinggi ditempati oleh Allah Swt. Diantara laki-laki dan perempuan tidak dipisahkan secara hirarki. Ketinggian kekuasaan Allah dengan manusia berjarak 
sama antara laki-laki dan perempuan. Tinggi rendahnya derajat manusia tidak ditentukan oleh jenis kelamin, ras, bangsa, golongan, tetapi oleh taqwanya.

Pada saat laki-laki atau perempuan menempatkan dirinya "di atas" yang lain, maka ia menempatkan diri mendekati kekuasaan Allah atau menyamainya (syirik), karena secara metafisik hanya ada khalik (Allah Swt) dan makhluk (laki-laki dan Perempuan), sebagaimana gambar kedua. Seseorang yang berimajinasi bahwa dirinya di atas yang lain, sebenarnya ia telah menderita penyakit syirik, dosa yang tak terampunkan, kecuali dengan pertobatan yang sungguh-sungguh.

Dalam paradigma tauhid, eksistensi laki-laki dan perempuan, tidak hanya berarti sama, lebih dari itu, keduanya dianggap sebagai satu (oneness) dalam kesatuan Allah. Melalui paradigma tauhid, fungsi sosial dan politik akan didasarkan pada ukuran kapasitas dan kapabilitas manusia, bukan karena dia laki-laki atau perempuan.

Dalam membangun relasi fungsional dalam kehidupan masyarakat, Wadud mengembangkan konsep diri (potensi individu) demi kemajuan hidup manusia. Kesetaraan individu merupakan kunci dalam mencapai kemajuan tersebut. Hanya saja budaya sebagai struktur dominan justru melahirkan relasi gender yang jauh dari spirit egalitarianisme.

Bagi Wadud ada beberapa aspek penting dalam menentukan relasi gender dalam kehidupan sosial. Yakni pertama, perspektif yang lebih demokratis mengenai hak dan kewajiban individu baik laki-laki ataupun perempuan di dalam masyarakat. Kedua, dalam pembagian peran tersebut hendaknya tidak keluar dari prinsip umum al-Qur'an tentang keadilan sosial, pengahargaan atau martabat manusia, persamaan hak di hadapan Allah, dan keharmonisan dengan alam. Ketiga, relasi gender hendaknya secara gradual turut membentuk etika dan moralitas bagi manusia. Ketiga aspek relasi gender ini menjadi prinsip utama sebuah 'relasi fungsional' yang tujuannya tidak lain adalah merealisasikan misi penciptaan manusia di dunia, yaitu khalifah fi al-ardi. 
Semangat gender Wadud, berprinsip pada teori etika, moral dan keadilan. Peran masing-masing individu dalam masyarakat mengindikasikan kelebihan masing-masing dari laki-laki dan perempuan. Prinsip inilah yang diterangkan oleh al-Qur'an sebagai konsekuensi dari potensi kebebasan yang dimiliki manusia dalam mengatur kehidupan mereka (khalifah). Khalifah tidak identik dengan kekuasaan laki-laki atas perempuan tetapi khalifah ini lebih diartikan sebagai wali, penganti dalam artian sosok seorang khalifah harus memiliki sifat dan karakter seperti yang di wakilinya, yaitu Tuhan. Khalifah membawa amanah yang mulia, sebagai agen moral, agen perubahan dalam rangka mencari ridho Allah.

Kesimpulan dari tawaran Wadud adalah; kekuatan atau outoritas penafsiran pada term (objek), siapa penafsirnya, dan bagaimana latarbelakangnya. kesalahan penafsiran pada term gender, keadilan, kesetaraan martabat, tauhid, dan khalifah yang harus di kaji ulang. Islam punya prinsip-prinsip univeral tentang moral, keadilan, dan kesetaraan gender. Prinsip ini yang harus diperhatikan.

Ruang lingkup penelitian yang dilakukan Amina Wadud adalah berkaitan intepretasi di kalangan umat Islam (khususnya) memandang relasi atau kedudukan perempuan dan laki-laki. Ia menjawab problem yang berkaitan tentang perempuan dengan bersumber pada al-Qur'an dengan menawarkan cara/ metode dan pendekatan dalam memahami sebuah teks (al-Qur'an). Fokus perhatian Wadud adalah otoritas penafsiran pada prinsip feminisme, keadilan gender, ayat-ayat tentang keadilan sosial dan kesederajatan manusia dan beberapa faktor yang menyebabkan marjinalisasi peran perempuan.

Amina Wadud menyajikan pemahaman komprehenshif tentang konsep keadilan sosial dan kesetaraan derajat manusia, prinsip dasar Islam, terutama pandangan miring tentang perempuan, melalui metode penelitian gender dalam al-Qur'an.

Kontribusi lainnya adalah memberikan perspektif penafsiran baru terhadap terma-terma strategis namun rawan diselewengkan seperti Islam, Tauhid, Taqwa, 
Syari' ah dan khilafah.yang dihasilkan dari penafsiran. Ia menemuka kata kunci "Prior Text", yaitu cultural background, prejudice-prejudice yang melatarbelakangi mufassir dan mempengaruhi perspektif mufassir untuk mendeteksi ada tidaknya penafsiran yang bias.

Metode tafsirnya yang komprehensif dapat digunakan untuk mendukung lahirnya konsep-konsep kunci dalam bidang ekonomi Islam. Masalah keadilan dan produktifitas yang menjadi persoalan klasik ekonomi dapat diperbaiki dengan pendekatan tafsir Amina Wadud. Ketimpangan ekonomi antar wilayah dan geografis dapat diperbaiki dengan keadilan akses. Kesempatan yang sama besar atas semua masyarakat terhadap sumberdaya ekonomi dengan sendirinya mampu memberikan solusi terhadap persoalan ketimpangan ekonomi.

Produktifitas dan literasi keuangan syariah terbukti mampu meningkatkan peran serta masyarakat dalam berbagai level dan struktur sosial. Pengalaman program grameen bank di Bangladesh, yang memberikan kesempatan lebih luas kepada perempuan dari golongan miskin untuk mengakses ke bank ternyata mampu meningkatkan kesejahteraan keluarga. Pelibatan strategis perempuan dalam berbagai level, perluasan peluang akses perempuan dalam berbagai level membuat ekonomi lebih berkembang.

Metode tafsir Amina Wadud dapat membantu persoalan ekonomi syariah memecahkan masalah-masalah yang tidak dapat diselesaikan melalui tafsir-tafsir konvensional. Kebutuhan tafsir dan pendekatan fiqh yang lebih segar dan komprehensif sangat diperlukan untuk menghadapi dinamika ekonomi Islam yang tengah tumbuh. Produk-produk keuangan syari'ah menghadapi tantangan fleksibilitasnya dalam memenuhi kebutuhan konsumen. Maka metode tafsir Amina Wadud memberikan peluang untuk menjawab kebutuhan tersebut.

\section{Metode}


Beberapa faktor yang menjadi kegelisahan akademik Amina wadud diantaranya : Struktur masyarakat yang patriarki telah menyebabkan perempuan terpinggirkan dalam ruang domestik. Sehingga perannya dalam masyarakat kurang dibandingkan saudaranya yang laki-laki. Dalam pandangan Khaleed Abou al-Fadhl, setidaknya ada dua hal yang menjadi perhatian kajian gender Amina Wadud, yaitu : struktur patriarki dalam gender dan ketidakadilan gender yang menyertai budaya patriarki dalam masyarakat.

Ketidakadilan gender yang disebabkan oleh penafsiran. Para mufasir, mayoritas laki-laki, dengan latar belakang sosial dan pengalamannya memberikan penafsiranalQur'an secara bias, dinilai telah menyudutkan perempuan dalam perannya ditengah publik dan menghasilkan paradigma yang tidak adil terhadap perempuan. Model penafsiran dari para mufasir, menghasilkan produk fiqh, term-term dan perlakuan yang tidak adil terhadap perempuan. Banyak ayat-ayat yang tidak menerapkan prinsip universalitas Islam dan konsep keadilan/ kesetaraan antara perempuan dan laki-laki. Karenanya Amina Wadud mempunyai perhatian yang serius terhadap terminologi atau pendefinisian suatu objek.

Amina wadud juga mempunyai kegelisahan tentang tantangan dalam belajar dan mengajar dalam kajian wanita muslim, kegelisahan amina wadud tercermin dengan pengalamannya meneliti dan mengajar di akademi U.S (Amerika). Daerah Amerika utara tempat terbesar dalam kajian gender termasuk wanita dan agama.

Al-Qur'an sebagai pedoman universal, tidak pernah terikat ruang dan waktu, latar belakang daerah ataupun jenis kelamin yang selanjutnya bernilai abadi dan tidak membedakan jenis kelamin, untuk itu Wadud berusaha menghadirkan pandangan ayatayat yang netral tentang gender. Al qur'an sebagai sumber utama pemandu umat Islam beragama, punya posisi penting untuk melakukan perubahan mendasar di berbagai segi kehidupan umat Islam. Sangat disayangkan apabila tafsir al Qur'an tanpa disadari menjadi dominasi Pria, sehingga belakangan disadari tafsirnya pun sangat maskulin. Maka al Qur'an terbuka untuk diberi pemaknaan ulang, dan Aminah Wadud berperan 
bersama perempuan perempuan dari berbagai negara seperti Fatimah Mernisi dari Maroko dan Aisyah Bintusy Syathi dari Mesir melahirkan tafsir yang tidak bias gender.

Amina wadud ingin membangkitkan peran perempuan dalam kesetaraan relasi gender, dengan berprinsip pada keadilan sosial dan kesetaraan gender. Realitas dalam Islam menunjukkan mengapa peran perempuan terbelakang dari pada laki-laki (patriarki). Dia juga ingin menyelamatkan perempuan dari konservatifme Islam. Menurut Amina Wadud banyak hal yang menyebabkan penafsiran miring tentang perempuan; kultur masyarakat, kesalahan paradigma, latar belakang para penafsir yang kebanyakan dari laki-laki, oleh karena itu ayat tentang perempuan hendaklah ditafsirkan oleh perempuan sendiri berdasarkan persepsi, pengalaman dan pemikiran mereka.

\section{Hasil}

Topik penelitian penting, karena metode tafsir ini memberikan peluang yang lebih besar dan perlakuan yang lebih adil bagi perempuan dalam bidang ekonomi. Tafsir al Qur'an dapat ditempatkan lebih relevan dengan dinamika sosial masyarakat dalam mencapai kesejahteraan. Islam seringkali digunakan untuk mengabsahkan subordinasi dalam setiap tradisi. Usaha Amina Wadud dapat dilihat sebagai cara untuk memberi solusi terhadap ketidakadilan penafsiran tentang perempuan. Upaya ini penting untuk menghilangkan ketimpangan relasi gender, laki-laki dengan perempuan dikalangan umat Islam. Subordinasi inilah yang membelenggu potensi besar yang dimiliki perempuan.

Amina Wadud sendiri merasa punya keterbatasan pengertahuan tafsir al-Qur'an yang menyangkut perempuan. Tetapi dengan latarbelakang pengalaman dan pendidikannya ia dapat dikatakan sebagai wakil umum (the common agents) yang harus diserap secara bijak oleh wakil khusus (The special agents) yang dipandang memiliki otoritas (authority). Ia menyadari bahwa ketertarikan para intelektual Islam terhadap persoalan perempuan bukan hal yang baru, hanya saja ia berupaya untuk 
menjawab persoalan tentang perempuan dengan bersumber pada al-Qur'an. Apalagi di era kritik pasca modern saat ini ketika setiap landasan ilmu pengetahuan ditantang untuk bergerak melampaui nilai-nilai tertentu diperlukan suatu pemahaman terhadap politik wacana gender dalam kontek Islam secara global.

Metode Amina wadud yang menawarkan penafsiran ayat-ayat perempuan secara komprehensif akan menghasilkan tafsir yang lebih progresif. Di bidang ekonomi Islam penafsiran ini dapat menaikkan peran perempuan dalam aktifitas bisnis. Memperluas kesempatan perempuan dalam mengeksplorasi sumberdayanya bagi pencapaian kesejahteraan keluarga. Membuka inovasi-inovasi baru dalam sektor ekonomi dan mu'amalah lainnya.

Pendekatan dekonstruksi subjektifitas penafsir Amina Wadud dapat membongkar ketidakadilan. Keadilan ekonomi, berarti peningkatan mobilisir sumberdaya manusia. Pelibatan sumberdaya manusia yang lebih besar dapat memanfaatkan peluang-peluang ekonomi yang tidak tergarap. Peningkatan produktifitas ekonomi bisa mendorong pertumbuhan ekonomi, inflasi yang terkendali, penyerapan tenaga kerja dan menguatnya investasi serta tabungan masyarakat. Penafsiran yang tidak bias gender, mengembalikan posisi perempuan terhadap hak dan akses ekonomi perempuan.

Penafsiran ajaran agama pada kitab suci menempati posisi penting, karena pada titik ini bias gender secara sistemik mulai berlangsung untuk membentuk prilaku beragama umat Islam. Dalam ranah sosiologis, dimana Islam dilihat sebagai fenomena sosio kultural, maka lingkungan sosial akan sangat dipengaruhi oleh penafsiran dalam membentuk eksistensi Islam.

\section{E. Pembahasan}

Pembahasan dalam artikel penelitian menjelaskan hasil yang didapat dari penelitian. Penulis menyusun, menganalisis, mengevaluasi dan menginterpretasi serta membandingkan hasil temuan terbaru dengan temuan dari penelitian yang telah ada. 
Hindari pengulangan kalimat baik dari pendahuluan, metode maupun hasil. Jumlah paragraf pembahasan sebaiknya lebih panjang dari pendahuluan. Konsistensi artikel mulai dari judul hingga pembahasan harus diperhatikan. Kelemahan penelitian dan saran untuk pengembangan penelitian selanjutnya dijabarkan pada bagian ini.

\section{F. Simpulan}

Keadilan merupakan prinsip yang penting dalam Islam. Berbuat adil lah sesungguhnya berbuat adil akan mendekatkan dirimu kepada taqwa, demikianlah Allah memberi petunjuk. Sementara itu, ketidakadilan terhadap perempuan yang sistemik dapat ditemukan dalam berbagai agama, peradaban, kebudayaan dan bangsa di dunia. Berbuat tidak adil bagi umat Islam sesungguhnya menjauhkan diri dari ketaqwaan, suatu derajat yang menentukan perbedaan derajat antara muslim satu dengan muslim lainnya. Keadilan menjadi nilai intrinsik ekonomi syariah akan menghasilkan konsep konsep ekonomi yang lebih baik apabila menggunakan metode tafsir

Amina Wadud menyampaikan suatu perspektif penafsiran dengan methode yang ilmiah untuk menjawab ketimpangan dalam relasi gender, sehingga potensi perempuan yang terabaikan karena budaya patriarki dapat diposisikan secara semestinya sebagai khalifah Allah.

\section{Referensi}

Abdullah ,Taufiq (et.al) Ensiklopedi Tematis Dunia Islam, Dinamika Masa Kini .Jakarta: Ichtiar Baru Van Hoeve. cet I, 2002

Abou al-Fadl ,Khaled, Speaking in God's Name : Islamic Law, Authority, and Women Oxford: Oneworld, 2001

Cleves ,Mosse Julia, Gender dan Pembangunan Yogyakarta: Pustaka Pelajar, 1996

Moris, ,Brian .Antropologi Agama : Teori-teori Agama Kontemporer, terj. Imam Khoiri Yogyakarta : AK Group, 2003

Wadud ,Amina, Inside Gender J ihad, Women's Reform in Islam .Oxford: Oneworld Publication, 2006

Wadud,Amina. Qur'an and Women, Rereading the Sacred Text from a Women Perspective .Oxford: Oneworld University Press, 1999 